\title{
SPATIAL ANALYSIS OF TOURISM SERVICES AND ATTRACTIONS OF THE 'CIRCUITO DOS DIAMANTES’: SUPPORT FOR TOURISM PLANNING
}

\author{
Laís Murta Alves Maia a; \\ Guilherme Fortes Drummond Chicarino Varajão b;
}

\begin{abstract}
The 'Circuito dos Diamantes', (Diamond Circuit) is a region comprising 15 municipalities located in the Espinhaço mountain Range of Minas Gerais, Brazil. This study presents the results of a spatial analysis carried out with a Geographic Information System (GIS), using data from the georeferenced tourism inventory. The methodological stages of this exploratory research were: bibliographical research and review; standardization of the inventory data in the GIS software; map making; and analysis of tourism services and attractions. The analysis resulted in density maps of tourism attractions and services, in which the main problems identified are outlined here. There is a lack of tourism services in certain areas and a significant concentration of services around the Estrada Real highway and the cities of Diamantina and Serro. The tourism inventory was incomplete for municipalities with less tourism importance, showing a need for further investments in this basic instrument of tourism planning.
\end{abstract}

\section{KEY-WORDS}

Geographic Information System

Tourism inventory

Diamantina 


\section{INTRODUCTION}

The main object of consumption, transformation, and building of new localities in tourism is the geographical space (Cruz, 2003). Tourism is also a form of spatial displacement (Nicolàs, 1996). Tourism is described by Panosso Netto (2010) as a person's displacement and return to his/her place of residence, for known or unknown purposes, that involves communication between people and the use of technology, among many other aspects, promoting an exchange of experiences and having an impact in many other ways. It is, therefore, as much a spatial phenomenon, as it as a social phenomenon (Fratucci, 2000). Tourism is an activity that results from the development of societies establishing interpersonal relationships. As such, tourism is considered one of the most important activities in the global economy (Barbosa, 2004).

Tourism performance is unique in each location. The elements of tourism differ from one location to another and are responsible for the dynamics and formation of a geographic space (Tulik, 1990). For this to occur in an organized manner, planning is necessary (Dias, 2003). Planning should be carried out with the specific characteristics of the location in mind, considering the different variables involved in the process. Therefore, it is necessary to understand the relationship between tourism and geographical space. There are several theoretical contributions to this field, including geography (Santos, 2014).

Understanding this relationship is crucial for planning tourism activity, including the collection and analysis of information (Scheuer, 2011). Planning helps minimize potential problems and serves as a guide for future achievements (Solha, 2006). Petrocchi (1998) defines planning as "the definition of a desired future and all the necessary measures for its materialization" (p. 19). Therefore, appropriate actions should be carried out in order to achieve the desired results. Tourism development should be focused on minimizing negative impacts and promoting positive ones (Cooper, 2001 cited by Vieira et al., 2017). Thus, planning involves gathering accurate information from the real environment, requiring the assistance of computer tools (Bissoli, 1999). Geoprocessing is an effective tool for gathering, organizing and analyzing information accurately (Silva, 2010 cited by Carvalho et al., 2012).

Map generation using this technology allows crossreferencing of data using GIS (Oliveira, 2005). These maps can assist in the observation and evaluation of the tourism potential of a place, and in the planning (Carneiro et al., 2005). According to Câmara and associates (1998) and Dangermond (1992), GIS consist of computational systems capable of storing, manipulating, analyzing and presenting georeferenced data. Burrough and Mcdonnell (2005) define GIS as "a powerful set of tools for collecting, storing, retrieving at will, transforming and displaying spatial data from the real world for a particular set of purposes" (p. 11). Nodari et al. (2006) emphasize the importance of this technology in tourism; for them "the amount and type of tourism data requires a management tool that addresses the needs for an instrument that optimizes the storage, analysis and manipulation of such data" (p. 217). The use of GIS enables greater ease, reliability and efficiency in the processing of information related to geographic space, and is an essential tool for tourism planning (Scalco, 2006).

The use of technology in tourism provides a powerful instrument that enables the creation of new strategies aimed at economic growth (Sousa \& Fernandes, 2007), and it is a fundamental tool for resolving problems and visualizing new opportunities (Rossato, 2004).

Georeferenced data contribute to the development of tourism products and services, and cross-referencing these data allows a broader view of the elements being studied (Souza \& Fernandes, 2007). Duque and Mendes (2006) point out that the use of GIS allows the establishment of relationships between different types of information, such as: the distribution of tourism services (accommodation and food); accessibility to attractions and facilities; tourism infrastructure support; mapping outbound tourism hubs and the routes to reach destinations; and information about tourism demand, enabling any imbalances between services to be identified. GIS can provide information on environ- 
mental aspects, landscapes, tourist attractions, services and infrastructure (Rossato, 2004). Ramón Morte (1997), quoted by Ladwig (2012), shows that this tool is also capable of obtaining geographic information at a remote distance, using online satellite imagery, among other sources, enabling its use from anywhere in the world.

An example of the use of GIS in tourism is a study carried out Gutiérrez and associates (2017) who demonstrated, through bivariate spatial autocorrelation, the spatial relationship between hotel locations and Airbnb accommodation. Multiple regression analysis showed the explanatory factors of the locations, which were very similar for both types of accommodation.

The tourism inventory is an important tool for the study of tourism services supply, and is considered an indispensable source for tourism managers. In 2017, a tourist inventory layout was implemented in Minas Gerais with georeferenced data, allowing its representation in a GIS. The inventory is a government program required in all municipalities of the Minas Gerais tourism circuits. These circuits were created in 2001, aimed at promoting regional development. Decree no. 43.321 defines them as:

[...] a set of municipalities in the same region, with cultural, social and economic affinities that unite to organize and develop regional tourism activity in a sustainable way, through the continuous integration of municipalities, consolidating a regional activity (Minas Gerais, 2003, p. 1).

Oliveira and Santos (2006) highlight that the creation of these tourist circuits or routes was due to "the need to obtain competitive advantages, where the availability of tourism products and services should complement each other" (p. 333), aiming to increase the possibility of meeting tourists expectations. At that time, these organizations were presenting an innovative idea in the management of tourist activity. This method yielded positive results, such as increased efforts for tourism promotion and development, professional training, conservation of cultural and natural heritage, improved quality of life for communities and better services for tourists.
Thus, the objective of this study is to present a spatial analysis of the services and attractions of the tourism of Circuito dos Diamantes. This will be performed through thematic maps elaborated in a Geographic Information System (GIS), using the tourism inventory as the main database. This representation through maps will allow a better understanding of spatial distribution of tourism services in Circuito dos Diamantes, helping tourism planning in this region.

\section{METOdOLOGY}

This study is an exploratory research of tourism services of the Circuito dos Diamantes. Exploratory research is understood as a way of studying a situation that has not yet been researched, making considerations and creating hypotheses about themes not yet known (Gil, 2008). Initially, a literature review was carried out investigating the themes of tourism planning, tourism geography, spatial analysis of tourism, geographic information systems and tourism. The georeferenced tourism inventory of the Circuito dos Diamantes, updated in 2018, was used as the main database. The key information used in this document was related to tourism attractions, accommodation, and food services.

The spatial analyses were performed by GIS using the software program ArcGIS, which allowed the elaboration of thematic maps. The cartographic bases, obtained through the Brazilian Institute of Geography and Statistics (Instituto Brasileiro de Geografia e Estatística [IBGE], 2000), are composed of municipal boundaries and road networks of Minas Gerais. Georeferenced vector data of the Estrada Real, the Biosphere Reserve of Serra do Espinhaço and conservation areas were gathered by the Instituto Pristino (2017). All the cartographic bases were transposed to the World Geodetic System 1984 DATUM.

The geographic information of attractions and tourism services were merged with its attributes, and the data were systematized in Microsoft Excel and then exported to ArcGIS. Spatial distribution and density analyses were performed using the Kernell interpola- 
tion technique, using statistical natural breaks divided into 5 classes, which represented the distribution keys (Very Low, Low, Moderate, High and Very High). With the buffer tool, the distances between the attractions and the food and accommodation services were measured, using radiuses of one, two, and three kilometers, to represent the relationships between attractions and services.

\section{RESULTS AND DISCUSSION}

Cunha (2018), manager of the Circuito dos Diamantes, states that the circuit was created in 2005, and was a pioneering project within the state. The agreement between several public agencies of Minas Gerais has resulted in regionalization. Initially, this organization covered only Diamantina, and its purpose was to plan tourism activity and preserve the city. Later on, Diamantina became associated with other adjacent municipalities. Diamantina is located at $290 \mathrm{~km}$ from the Minas Gerais capital, Belo Horizonte. The city is of great tourist interest, mainly for its architectural buildings, many of which have listed building status of the Instituto do Patrimônio Histórico e Artístico Nacional (IPHAN, 2013), and for the beauty of its natural surroundings. In 1999, it was included on the world heritage list of the United Nations Educational, Scientific and Cultural Organization (UNESCO) as a cultural site, further intensifying tourism activity in the city (Costa, 2009).

Currently, the Circuito dos Diamantes encompasses 15 municipalities: Alvorada de Minas, Carbonita, Datas, Diamantina, Couto Magalhães de Minas, Felício dos Santos, Gouveia, Monjolos, Presidente Kubitschek, Rio Vermelho, Santo Antônio do Itambé, São Gonçalo do Rio Preto, Senador Modestino Gonçalves, Serra Azul de Minas and Serro. Its headquarters are located in the city of Diamantina, which is the city that receives the largest flow of tourists in the circuit (Cunha, 2018).

The purpose of the organization, Circuito dos Diamantes, is the development of tourism in these locations, promoting the activities in a sustainable manner and seeking for the consolidation of an identity. Therefore, this organization provides regional development and improves the quality of life of those involved. The associated municipalities have in common the diamond exploration period, presenting numerous cultural and natural attractions.

Tourism is an activity consisting of tangible and intangible products. The main attractions of this region are non-materialistic, and include the history and culture; it has an important collection of customs, gastronomy, music and religious practices that go back to the period of Portuguese colonization (Cunha, 2018). According to the Tourism Demand Survey in Minas Gerais, conducted in 2014 by the state government and the Instituto Qualitest Ciência e Tecnologia, around 21\% of those surveyed said they were interested in visiting the Circuito dos Diamantes. It occupies third place among the most important circuits. Therefore, the importance of implementing actions for the development of tourism in the Circuito dos Diamantes is evident

The area of this study is located in the Serra do Espinhaço, designated by UNESCO as a Biosphere Reserve (area of natural heritage). This region has great potential for the practice of ecotourism and adventure tourism. There are seven conservation areas in the Circuito dos Diamantes, as shown in Figure 1: one national park (Sempre Vivas), three state parks (Biribiri, Rio Preto and Pico do Itambé), one conservation area (Águas Vertentes), one ecological station (Mata dos Ausentes) and one natural monument (Várzea do Lageado and Serra do Raio).

Tourism demand is related to the attractiveness of a destination. Tourist attractions are anything that can capture the tourist's interest, and are the main motivators for visiting a location. Figure 2 illustrates the density of the inventoried attractions of the Circuito dos Diamantes, ranging from very low (one or less), light yellow, to very high (18 or more), dark red. In total, there are 74 cultural attractions and 71 natural attractions, often close to urban areas.

The cities with more attractions are Diamantina (29) and Serro (18). Milho Verde and São Goncalo do Rio das Pedras, which are districts of Serro, have higher 
Figure 1- Location of Circuito dos Diamantes

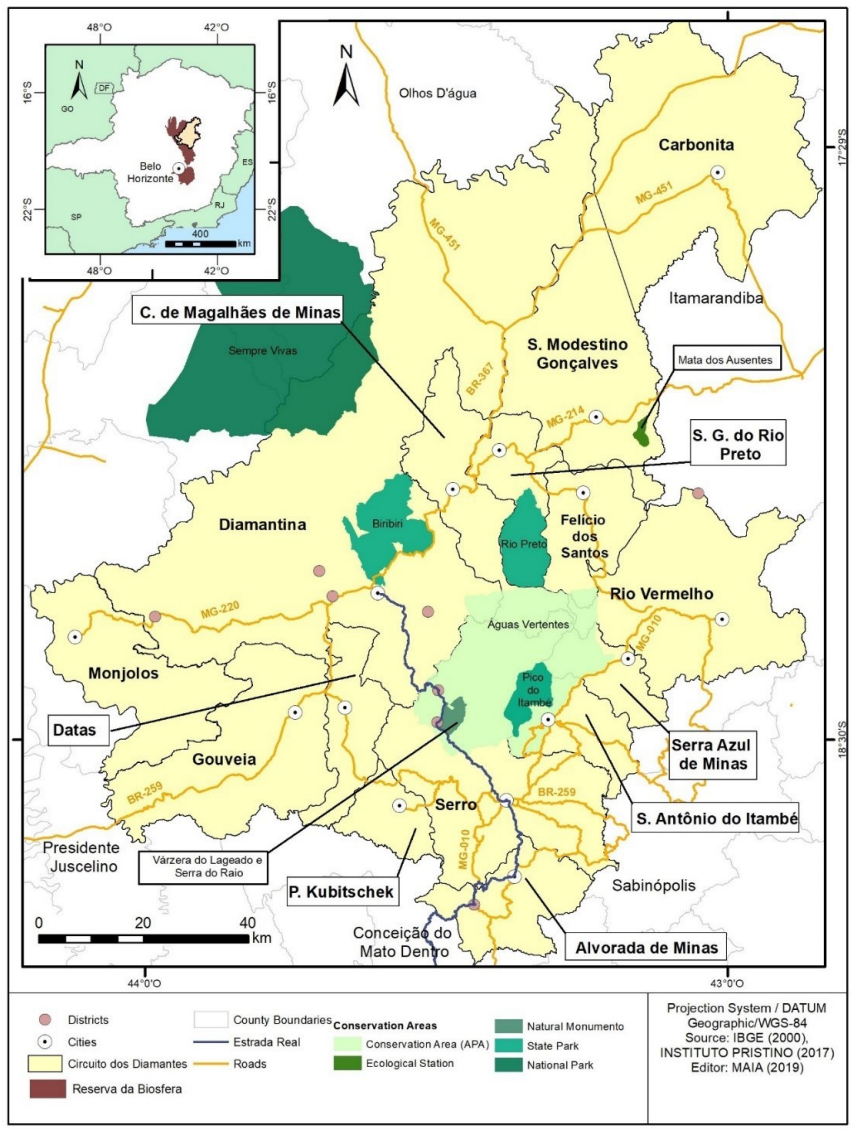

Source: Developed by the authors.

numbers (each has eight). There is a concentration of tourist attractions on the axis or around the Estrada Real highway, the main route by which gold and diamonds were transported through Minas Gerais and of great commercial and economic relevance (Santos, 2001).

Colonial cities, with their architectural and cultural heritage, are increasingly valued by tourists. Cultural tourism involves the histories of communities and their social memory, so that people from other locations can learn about their culture. Tourism is also a way of conserving and treasuring these elements (Barretto, 2000).

There are 74 inventoried cultural attractions, distributed as follows: $38 \%$ churches; $11 \%$ cheese making attractions; $8 \%$ chapels; $8 \%$ historical houses or buildings; $8 \%$ tourism farms and ranches; $7 \%$ museums; 3\% tourist art and crafts; and $17 \%$ other varied cultural attractions. The number of religious attractions suggests great potential for developing religious tourism in this area.

One of the most well-known aspects of intangible heritage of the region is the artisan way of producing a type of cheese called 'queijo minas do Serro'. This is a technique that has been passed down through generations for more than three hundred years. The technique originally came from Serra da Estrela, in Portugal. In 2002, the cheese-making method was registered by the Instituto Estadual do Patrimônio Histórico e Artístico of Minas Gerais (IEPHA/MG) as an intangible heritage. In 2008, it became registered as an intangible heritage of Brazil (Melo \& Silva, 2014). This product, which provides the main economic support for several families of this region, became a tourist attraction, representing $11 \%$ of the cultural attractions of the circuit. Besides gastronomic tourism, another segment that this delicacy promotes is rural tourism, through visits to farms where the cheese is produced.

Figure 02 - Distribution of Tourist Attractions in the region of Circuito dos Diamantes )

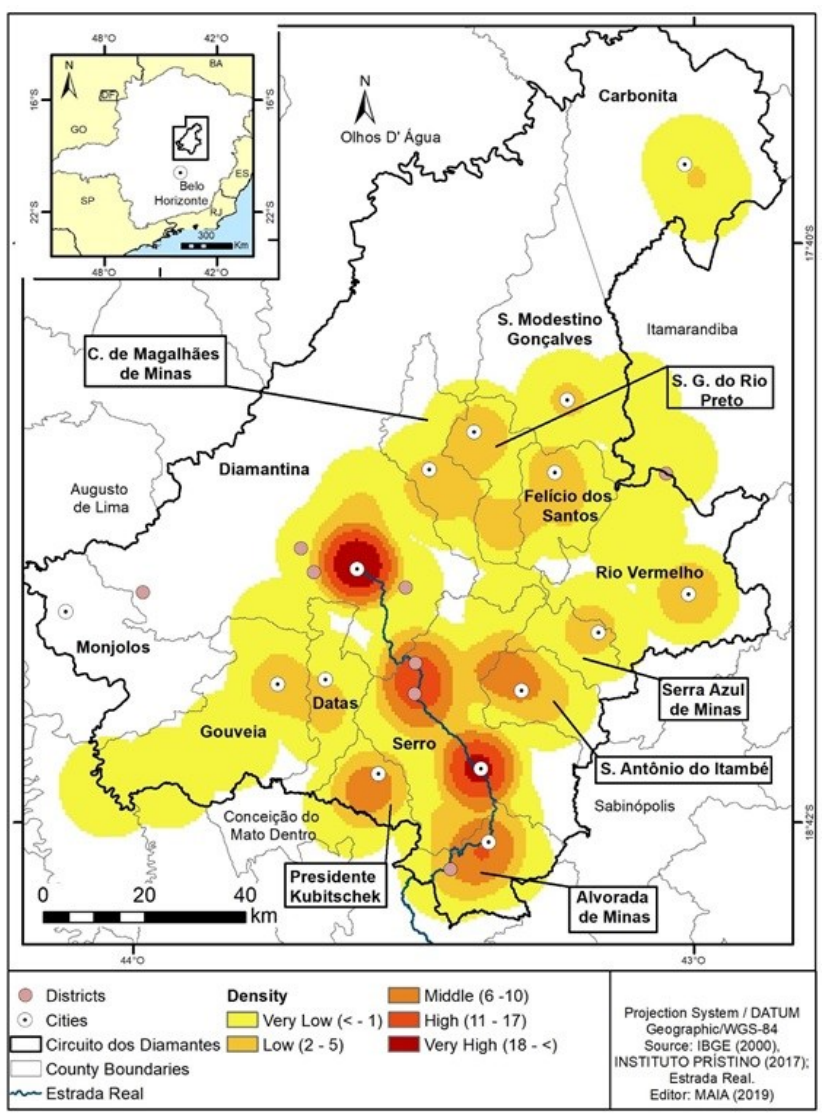

Source: Developed by the authors 
Natural attractions are elements of nature that can capture tourists' interest (César \& Stigliano, 2005). They are characterized according to the particularities of the sites, e.g., relief and biome. The Circuito dos Diamantes is located at the intersection of three major Brazilian biomes: Cerrado (tropical savanna), covering most of the territory, Caatinga (dry shrubland), and Mata Atlântica (native Atlantic forest) (Gontijo, 2008). The highest regions, above 900 meters, have Campos Rupestres, or altitude fields (Minas Gerais, 2004). The present high species endemism is due to the isolation provided by the altitude difference (Giulietti et al., 2000). These elevated areas are important for recharging aquifers, and the topography favors the formation of waterfalls, which are attractive for tourism.

The objective of ecotourism is to promote environmental conservation with the participation of local communities (Ministério do Turismo, 2010). Actions to promote ecotourism in the region are therefore needed, linking conservation with economic gains for the community. There are 71 natural attractions in the Circuito dos Diamantes, as follows: 69\% waterfalls; $10 \%$ conservation areas; 9\% mountains and ranges; $9 \%$ caves; and $3 \%$ other attractions. Access to these attractions is along trails or footpaths that allow contemplation of the landscape, adding more value to the visitor's experience.

Natural attractions are also concentrated around 'Estrada Real'. There are 12 attractions located in Alvorada de Minas, 29 in Diamantina, and 18 in Serro. The districts of Serro, which are also part of the Estrada Real, are significant: Milho Verde has 11 tourist attractions while São Gonçalo do Rio das Pedras has eight. Santo Antônio do Itambé is also of significant tourism interest, with 10 attractions.

The remaining sites have low appeal, with one or less attractions (light yellow). Therefore, a more in-depth study of these locations is needed in order to identify new potential. Places with untapped tourism potential are those with the capability to attract tourists in the future (Piatzchaki, 2014).
The World Tourism Organization (Organização Mundial do Turismo [OMT], 2001) defines tourism as an activity that involves the displacement of people from their usual environment, with at least an overnight stay in the destination. The development of tourism is directly related to the service sector. The accommodation sector has great relevance, because hotels and other accommodation establishments are needed if tourists are to stay in a destination for several days (Goeldner et al., 2002).

Figure 3 shows the number of accommodation services, ranging from very low (one or less), through light yellow, to very high (18 or more), dark red. There is an inventory of 80 registered companies and establishments, as follows: $61 \%$ inns; $28 \%$ hotels; $4 \%$ campsites; $3 \%$ hostels; $3 \%$ roosts; and $1 \%$ motel.

From the spatial distribution, it can be seen that there are more accommodation services along the Estrada Real axis. The main concentrations are in Diamantina, Serro, Milho Verde and São Gonçalo do Rio das Pedras. Other locations have very low (one or less) and low (between two and five) numbers of accommodation establishments.

Due to the close relationship between tourist attractions and services, an analysis was performed using the buffer tool, measuring the distance between these two elements. The buffer radiuses were divided into three categories: one, two and three kilometers. Most of the accommodation establishments are strategically located, as only $3 \%$ of all these establishments are more than three kilometers from a tourist attraction.

Considering a two-kilometer range, this value increases to only $4 \%$ and, within one kilometer, it increases to about $13 \%$. Therefore, $87 \%$ of all the inventoried tourist attractions are within one kilometer from an accommodation service, i.e., within walking distance. Li and associates (2015) reached similar conclusions, stating that hotel location is related to land use, tourist attractions, transportation routes, and economic variables. Therefore, the location of accommodation services is crucial for the success of a business (Yang et al., 2015, Shoval et 
al., 2011).

Nonetheless, some natural attractions are further away from an accommodation service. It is well known that some of these attractions are in remote areas. Tourists tend to visit the attractions during the day and return to the urban center at night (Silveira \& Medaglia, 2014).

Figure 3 - Distribution of Accommodation Services in the region of Circuito dos Diamantes

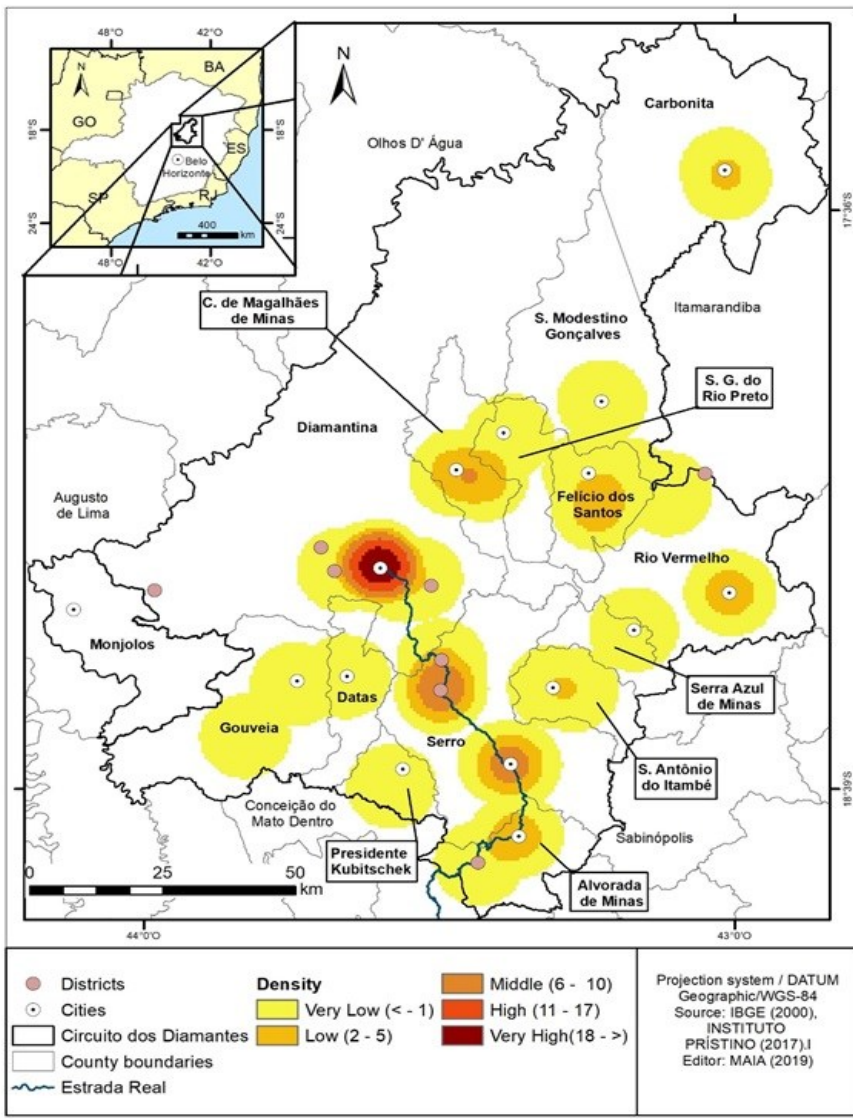

Source: Developed by the authors.

The World Tourism Organization (WTO, 2001) highlights that tourist spending goes far beyond accommodation, involving the consumption of food, transport and leisure activities. There are few inventoried food services, totaling 72, with: 46\% restaurants; $33 \%$ bars, beer houses and snack bars; $15 \%$ tea houses, coffee shops, bakeries and patisseries; $4 \%$ ice cream shops; $1 \%$ juice bars; and 1\% other. Figure 4 shows these data in spatial form. There is also a concentration of establishments around the Estrada Real. Some municipalities have a very low number, (one or less), light yellow, such as Presidente Kubitschek, Serra Azul de
Minas and Santo Antônio do Itambé. The cities of Carbonita, Felício dos Santos and Monjolos have no inventoried food services.

Figure 4 - Distribution of Food Services in the region of Circuito dos Diamantes

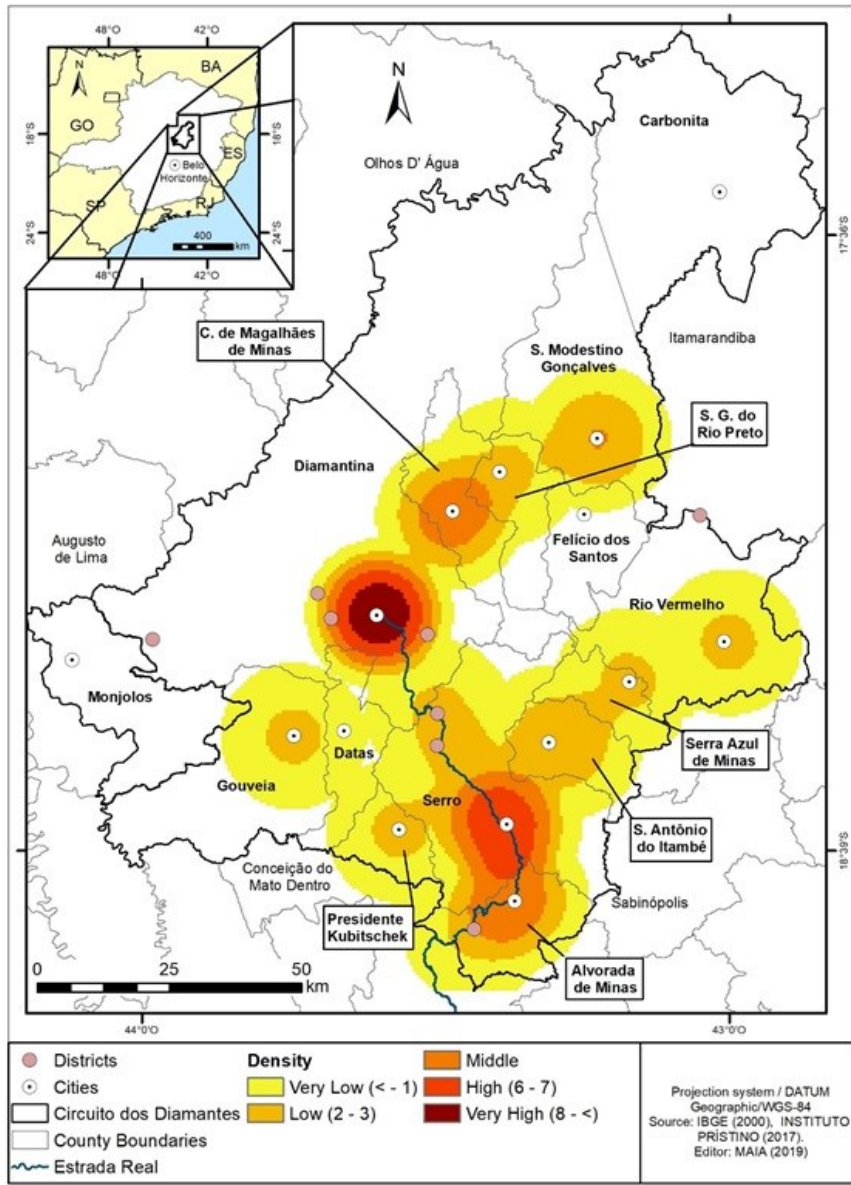

Source: Developed by the authors.

The food services are also linked to the distribution of attractions, as all the food establishments, except for one, are located within a radius of two kilometers from an attraction.

Table 1 allows a comparison of the inventoried elements of the Circuito dos Diamantes, representing a total of 145 attractions, both natural and cultural. There are 80 accommodation services and 72 food services. Given the number of municipalities that comprise the circuit, it is clear that the inventory was not performed properly, requiring greater attention from their managers and staff. 
Table 1- Circuito dos Diamantes Tourism Attractions and

\begin{tabular}{|l|l|l|l|}
\hline Cities & $\begin{array}{l}\text { Attrac - } \\
\text { tions }\end{array}$ & $\begin{array}{l}\text { A c c o m - } \\
\text { modation } \\
\text { Services }\end{array}$ & $\begin{array}{l}\text { F o o d } \\
\text { Services }\end{array}$ \\
\hline Alvorada de Minas & 14 & 4 & 7 \\
\hline Carbonita & 2 & 2 & 1 \\
\hline $\begin{array}{l}\text { Couto Magalhães de } \\
\text { Minas }\end{array}$ & 5 & 6 & 5 \\
\hline Datas & 3 & 1 & 0 \\
\hline Diamantina & 30 & 34 & 12 \\
\hline Felício dos Santos & 5 & 5 & 0 \\
\hline Gouveia & 6 & 2 & 7 \\
\hline Monjolos Kubits- & 9 & 0 & 0 \\
\hline $\begin{array}{l}\text { Presidente } \\
\text { chek }\end{array}$ & 7 & 1 & 2 \\
\hline Rio Vermelho & 9 & 2 & 4 \\
\hline $\begin{array}{l}\text { Santo Antônio do } \\
\text { Itambé }\end{array}$ & 145 & 80 & 72 \\
\hline $\begin{array}{l}\text { São Gonçalo do Rio } \\
\text { Preto }\end{array}$ & 7 & 1 & 3 \\
\hline Senador Modestino & 3 & 1 & 6 \\
\hline Serra Azul de Minas & 3 & 1 & 21 \\
\hline Serro & 42 & 17 & \\
\hline Total & 297 & & \\
\hline $\begin{array}{l}\text { Total inventoried } \\
\text { elements }\end{array}$ & 9 & 2 & \\
\hline
\end{tabular}

Source: Developed by the authors.

\section{FINAL CONSIDERATIONS}

As previously explained, it is essential to elaborate a tourism plan based on an accurate tourism inventory of attractions and services. This work seeks to fill a gap, where planning is commonly developed without the support of scientific evidence. It is an unprecedented way of using data from the new tourism inventory of Minas Gerais, a government program that is being implemented in the state and is required in all the municipalities within the tourist circuit. This study is applicable to other locations with similar characteristics, assisting professionals in developing tourism plans based on inventories, with a focus on social and environmental responsibility.

Our results show that the tourism attractions and services of the Circuito dos Diamantes are concentrated around the Estrada Real and the main urban centers of Diamantina and Serro. This poses a key obstacle to the promotion of tourism activity in other parts of circuit, outside these centers.

For tourism development to occur, it is necessary to have services and attractions that will enable the development of products. However, there is an unequal distribution of services among the studied cities. The identification of tourist potential in these other municipalities is fundamental, so that tourism will be more evenly distributed within the territory. That is the starting point for promoting tourism in the circuit. The information presented here is strategic for investors and businesses to create new services and establishments close to attractions where these services are lacking, such as in the cities of São Gonçalo do Rio Preto and Santo Antônio do Itambé. Government involvement is also important for creating tourism infrastructure in those areas, including tourist information centers.

This research is of great relevance for the characterization of the studied area, highlighting its strengths and allowing a greater understanding of the distribution of consolidated attractions and services. The region has great potential for ecotourism, due to its natural attractions and its location at the intersection of three biomes of great importance and rich biodiversity. It is no surprise that the region has seven conservation areas, and is part of the Serra do Espinhaço biosphere reserve.

This study identifies considerable deficiencies in the provision of services in most municipalities, which is an important issue to overcome. Several attractions lack services in their vicinity, and further stud is recommended, to investigate the feasibility of implementing new food and accommodation services, the lack of which represents a serious barrier to the effectiveness of the public policy of tourism regionalization in inductive destinations, such as Diamantina. Inductive destinations are those that present "basic and tourist infrastructure as well as qualified attractions, and are capable of attracting and/or distributing a significant number of tourists to their surroundings and boosting the economy of the territories in which they operate" (Ministério 
do Turismo, 2007). The development of tourism products, in other municipalities and locations of the Circuito dos Diamantes is important to allow the spread of tourists from the main centers and to increase the time they spend in the region.

The cities of Carbonita, Felício dos Santos and Monjolos did not present any inventoried services or attractions. But it is known that these locations do have attractions and accommodation services, albeit in less abundance than in the main cities. This absence in these municipalities clearly shows the limitation and incompleteness of the tourism inventory, which urgently needs to be executed. Further studies are suggested, to qualitatively analyze the efficiency of the Minas Gerais regionalization policy, which encourages municipalities to join the circuits and to be capable, among other criteria, of receiving a share of government investments on tourism investment (Minas Gerais, 2009, 2010).

The proposals to contribute to the short-term tourism development of the circuit include simple, lowcost actions, such as identifying new attractions, creating and/or maintaining access trails, and ensuring appropriate signage for existing and new tourist attractions. These actions should be accomplished in partnership with conservation area managers and councils, as well as non-governmental organizations and civil associations.

Medium and long term actions can be conducted for sites that lack services and require more resources, such as incentives, improvement, and/or creation of tourism services and equipment. Professional training should also be encouraged in places where there is already a tourist flow, and in those with higher tourist potential. This potential can be identified by meticulously updating the inventory - a basic instrument for any consistent planning proposal.

The techniques and tools of GIS used in this study are applicable to various areas of tourism and allow analyses that goes beyond those performed in this work. The identification of tourist potential, such as mountains and waterfalls, by comparing altimetry differences with the waterways, is an example of an application that would be relevant to the studied region. GIS tools are low in cost and can be applied remotely in various areas of tourism, providing an economically viable way of producing reliable information about the studied objects

\section{REFERENCES}

Barbosa, F. F. (2004, September 22) O turismo como um fator de desenvolvimento local e/ou regional. Caminhos de Geografia, 10(14), 107-114. ISSN 1678-6343. Retrieved from www.ig.ufu.br/caminhos_de_geografia.html.

Barretto, M. (2000) Turismo e legado cultural: as possibilidades do planejamento. (2nd. ed.) São Paulo: Papirus.

$\begin{array}{llll}\text { Biodiversitas. } & \text { (n.d.). } & \text { Retrieved } & \text { from }\end{array}$ www.biodiversitas.org.br/rbse/rbespinhaco.asp

Bissoli, M. A. M. A. (1999). Planejamento turístico municipal com suporte em sistemas de informação. São Paulo: Futura.

Burrough, P. A. \& Mcdonnell, R. A. (2005) Principles of Geographic Information Systems. (6th. ed.) New York: Oxford University Press.

Câmara, G., Casanova, M. A., Hemarly, A. S., Magalhães, G. C., \& Medeiros, C. M. B. (1998) Anatomia de Sistemas de Informação Geográfica. Campinas: Unicamp.

Carneiro, A. M. C., Moura, A. C. M., Oliveira, R. H. de, Ramos, V. D. V., \& Santana, S. A. de. (2005). A representação em realidade virtual da Estrada Real: novos caminhos na Cartografia destinada ao Turismo. In: Anais Congresso Brasileiro de Cartografia. (pp. 1-5). Rio de Janeiro, Rio de Janeiro, Brasil, 22.

Carvalho, E. M., Balsan, R., \& Leite, E. F. (2012) Geoprocessamento Aplicado No Planejamento Turístico: Discussão Teórica. Revista Eletrônica Da Associação Dos Geógrafos Brasileiros, 15, 110-128. ISSN:1808-2653. Retrieved from https:// periodicos.ufms.br/index.php/RevAGB/article/view/609

César, P. A. B., \& Stigliano, B. V. (2005). Inventário turístico: primeira etapa de elaboração do plano de desenvolvimento turístico. Campinas: Editora Alínea.

Costa, E. B. (2009). A dialética da construção destrutiva na consagração do Patrimônio Mundial: o caso de Diamantina (MG). (Dissertação Mestrado em Geografia). Faculdade de Filosofia, Letras e Ciências Humanas da Universidade de São Paulo, São Paulo.

Cruz, R. C. A. (2003). Introdução à geografia do turismo (2nd. ed.). São Paulo: Roca.

Cunha, É. C. da. (2018, October). Interviewed by : L. M. A. Maia. Diamantina: Circuito dos Diamantes.

Dangermond, J. (1992). What is a Geographic information System 
(GIS). In: A. Johnson, I., C. Pettersson B., \& J. Fulton L. (Eds.) Geographic Information Systems (GIS) and Mapping - Practices and Standards. Philadelphia: ASTM STP 1126, American Society for Testing and Materials.

Decree no 43.321, de 8 de maio de 2003 (2003, May 8). Dispõe sobre o reconhecimento dos circuitos turísticos e dá outras providências. Minas Gerais, Belo Horizonte, Secretaria de Estado do Turismo.

Decreto no 45403, de 18 de junho de 2010 (2010, June 10). Regulamenta o critério "turismo" estabelecido na Lei no 18.030, de 12 de janeiro de 2009, que dispõe sobre a distribuição da parcela da receita do produto da arrecadação do ICMS pertencente aos Municípios. Minas Gerais, Belo Horizonte.

Dias, R. (2003). Planejamento do turismo: política e desenvolvimento do turismo no Brasil. São Paulo: Atlas.

Duque, R. C., \& Mendes, C. L. (2006). O planejamento turístico e a cartografia. (1st. ed.) Campinas, São Paulo: Editora Alínea.

Fratucci, A. C. (2000). Os Lugares Turísticos: Territórios do Fenômeno Turístico. GEOgraphia. 2(4), 121-132.

Gil, A. C. (2008). Como elaborar projetos de pesquisa. (5th. ed.) São Paulo: Atlas.

Giulietti, A. M., Harley, R. M., Queiroz, L. P., Wanderley, M. G. L., \& Pirani, J. R. Caracterização e endemismos nos Campos Rupestres da Cadeia do Espinhaço. In Cavalcanti, T. B., \& Walter, B. M. T. (Org.). (1st. ed. pp. 311-318) Tópicos atuais em Botânica. Brasília: SBB/CENARGEN.

Goeldner, C. R., Ritchie, J.R. B., \& Mcintosh, R. W. (2002) Turismo: princípios, práticas e filosofias. (8th ed.) Porto Alegre: Bookman.

Gontijo, B. M. (2008, December). Uma geografia para a Cadeia do Espinhaço. Megadiversidade, 4(1, 2), 7-15.

Governo de Minas, Minas e Sua Liberdade, \& Qualitest. (2014) Pesquisa de Demanda Turística no Estado de Minas Gerais: Alta e Baixa Temporada.

Gutiérrez, J., García-Palomares, J. C., Romanillos, G., SalasOlmedo, M. H. The eruption of Airbnb in tourist cities: Comparing spatial patterns of hotels and peer-to-peer accommodation in Barcelona. Tourism Management, v. 62, p. 278-291, 2017.

Instituto Brasileiro de Geografia e Estatística. (2000). Malhas digitais. Retrieved from hftp://geoftp.ibge.gov.br/ organizacao_do_territorio/malhas_territoriais/ malhas_municipais/municipio_2000/mg/

Instituto do Patrimônio Histórico e Artístico Nacional. (2013). Lista dos Bens Culturais Inscritos nos Livros do Tombo (19382012). Rio de Janeiro: IPHAN

Instituto Pristino. (n.d.) Baixe os arquivos .shp e .kml - Municipios de Minas Gerais

Ladwig, N. I. (2012, April - September). O Sistema de Informação Geográfica para o Planejamento e a Gestão Sustentável do Turismo. Revista Gestão e Sustentabilidade Ambiental, Florianópolis, 1(1), 19-32.
Lei 18030 de, 12 de janeiro de 2009. (2009, January 12). Dispõe sobre a distribuição da parcela da receita do produto da arrecadação do ICMS pertencente aos Municípios. Minas Gerais, Belo Horizonte. Retrieved from https:// www.almg.gov.br/consulte/legislacao/completa/completa -nova min.html? tipo $=$ LEI\&num $=18030 \&$ comp $=\& a n o=2009 \&$ texto $=$ consolida do

Li, M.; Fang, L., Huang, X., \& Goh, C. A spatial-temporal analysis of hotels in urban tourism destination. International Journal of Hospitality Management, 45, 34-43, 2015.

Melo, A. C. A., \& Silva, E. L. da. (2014) Queijo Minas Artesanal: Patrimônio Brasileiro Proibido e Oportunidade para o Desenvolvimento do Turismo Rural em Serro/MG. In: Anais do Festival das Cataratas - Fórum Internacional de Turismo do Iguassu. Paraná: Foz do Iguaçu, 8. Retrieved from http://festivaldascataratas.com/wp-content/ uploads/2014/01/9.-QUEIJO-MINAS-ARTESANAL.pdf.

Minas Gerais. (2004). Plano de Manejo do Parque Estadual do Biribiri. Encarte 3: Análise da Unidade de Conservação. Curitiba: Instituto Estadual de Florestas - SEMAD/IEF. Retrieved from http://www.terrabrasilis.org.br/ ecotecadigital/images/abook/pdf/2016/maio/ Mai.16.34.pdf

Ministério do Turismo. (2007). Destinos Indutores: Política de desenvolvimento do turismo nos destinos. Retrieved from http://www.turismo.gov.br/sites/default/turismo/ noticias/acontece/download acontece/ AirtonPereira_Destinos_Indutores_manhx_0408.pdf

Ministério do Turismo. (2010). Ecoturismo: orientações básicas. (2nd ed.). Brasília. Retrieved from http:// www.turismo.gov.br/sites/default/turismo/o_ministerio/ publicacoes/downloads_publicacoes/ Ecoturismo_Versxo_Final_IMPRESSxO_.pdf

Multifinalitário e Gestão Territorial, Florianópolis: UFCS.

Nodari, L. D. T., Becker, T., \& Canale, D. P. (2006). A aplicação do geoprocessamento como ferramenta de auxílio ao turis mo. In: Anais Congresso de Cadastro Técnico, 7.

Oliveira, I. J. de. (2005). A Cartografia Aplicada ao Planejamento do Turismo. Boletim Goiano de Geografia. Goiânia, Goiás. 25(1-2), 30-46.

Oliveira, J. M. S. R., \& Santos, A. C. (2006). O turismo como alternativa para o desenvolvimento da competitividade: uma análise da "rota dos tropeiros" no Oeste de Minas Gerais. FACEF Pesquisa, 9( 3), 332-342.

Organização Mundial do Turismo (2001). Introdução ao turismo. Tradução Dolores Martins Rodriguez Corner. São Paulo: Roca.

Panosso Netto, A. (2010). O que é turismo (1st. ed.) São Paulo: Brasiliense.

Petrocchi, M. (1998). Turismo: planejamento e gestão. (7th. ed.) São Paulo: Futura.

Piatzchaki, V. (2014). Análise da potencialidade turística do município de Irati - PR. Trabalho de Conclusão de Curso 
(Graduação em Turismo). Setor de Sociais Aplicadas, Universidade Estadual do Centro-Oeste - UNICENTRO, Irati, Paraná. Retrieved from https:// www.institutopristino.org.br/atlas/municipios-de-minasgerais/baixe-os-arquivos-shp-e-kml/

Rossato, A. (2004). Uso do SIG no Suporte ao Planejamento Turístico do Município De Pinhal Grande-Rs. Postgraduate Dissertation, Universidade Federal de Santa Maria, Programa de PósGraduação em Geomática, Santa Maria.

Ruschmann, D. van de M., \& Solha, K. T. (2006). Planejamento turístico. Barueri: Manole.

Santos, M. (2001). Estradas Reais. Belo Horizonte: Estrada Real.

Santos, N. P. (2014) Turismo, gestão e território. Caderno Virtual de Turismo. Edição especial: Hospitalidade e políticas públicas em turismo. Rio de Janeiro, 14(1), 66-86.

Scalco, R. F. (2006). A cartografia multimídia e a informação turística: uma análise de diferentes maneiras de disponibilizar a informação turística baseada nos recursos do geoprocessamento. Caderno Virtual de Turismo. 6(3). ISSN: 1677-6976.

Scheuer, L. (2011, October). Percepção geográfica e planejamento turístico: um estudo sobre a Sazonalidade. Turismo \& Sociedade. Curitiba, 4(2), 286-304.

Shoval, N., Mckercher, B., Ng, E., Birenboim, A. Hotel location and tourist activity in cities. Annals of Tourism Research, v. 38, n. 4, p. 1594-1612, 2011

Silveira; C. E., \& Mendaglia, J. (2011). A Demanda Turística Real da Cidade de Diamantina/MG. Estudios y Perspectivas en Turismo (En Línea), 20, 1-20.

Sousa, P. R. e, \& Fernandes, S. B. (2007). Aplicação dos Sistemas de Informação Geográfica no Turismo. Finisterra, XLII, 84, 105 $-118$.

Tulik, O. (1990). Turismo e repercussões no espaço geográfico. Revista Turismo em Análise, 1(2), 63-77. Retrieved from https://doi.org/10.11606/issn.1984-4867.v1i2p63-7

Vierira, R., Mussi, C. S., \& Pires, P. dos S. (2017) Estudo sistêmico da paisagem no empreendimento turístico "Ilha de Porto Belo" em Santa Catarina, Brasil, na perspectiva de sua sustentabilidade. Revista Brasileira de Pesquisa em Turismo. São Paulo, 11(2), 218-238. ISSN 1982-6125.

Yang, Y., Tang, J., Luo, H., Law, R. Hotel location evaluation: A combination of machine learning tools and web GIS. International Journal of Hospitality Management, v. 47, p. 14-24, 2015.

\section{CONTRIBUIÇÃO DOS AUTORES}

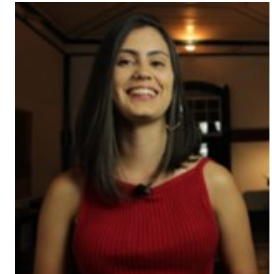

Laís Murta Alves Maia - Planejamento, execução e redação do artigo; fundamentação teórica, elaboração dos mapas, análises dos resultados e discussões.

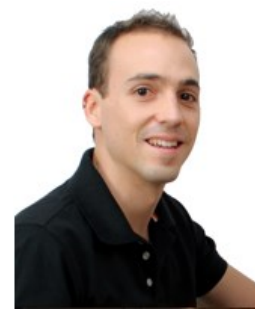

\begin{abstract}
Guilherme Fortes Drummond Chicarino Varajão - Elaboração do projeto; planejamento, execução, análise dos resultados, discussões e aplicabilidade; escolha dos procedimentos metodológicos, redação e revisão do manuscrito:
\end{abstract}

